Wiraraja Medika: Jurnal Kesehatan
https://www.ejournalwiraraja.com/index.php/FIK
2088-415x (Print)|2685-9998 (online)

\title{
Spiritual Status Related To Life Quality Of Elderly
}

\author{
Mujib Hannan ${ }^{1}$, Syaifurrahman Hidayat ${ }^{2}$ \\ 1,2Program Studi Keperawatan Fakultas Ilmu Kesehatan Universitas Wiraraja \\ ํㅣuㅣ@wiraraja.ac.id*2.2dayat.fik@wiraraja.ac.id \\ Corresponding author*
}

\begin{tabular}{ll}
\hline Informasi artikel & ABSTRAK \\
\hline Sejarah artikel: & Spiritual yang baik apabila dimiliki lansia akan membantu lansia dalam \\
Received: 11-10-2020 & menjaga hubungan lansia dengan tuhan serta orang sekitar dan lingkungan \\
Revised: 11-11-2020 & sehingga dapat menyadari dan mengetahui mengenai tujuan hidup \\
Accepted: 29-11-2020 & kedepannya. Lansia menderita berbagai gangguan kesehatan karena \\
\hline Kata kunci: & kerentanan terhadap banyak gangguan fisik dan mental. Kualitas hidup \\
Status spiritua, kalitas & pada lansia dapat dipengaruhi oleh banyak faktor lingkungan. Kualitas \\
hidup, lansia & hidup dikatakan baik apabila keadaan fisik dan psikisnya sehat dan \\
& berfungsi dengan baik. Metode penelitian menggunakan analitik korelasi \\
& dengan rancang bangun cross sectional, Populasi dalam penelitian iniadalah \\
& lansia yang berusia lebih dari 45 tahun, teknik pengambilan sampel dengan \\
& cara Simple Random Sampling dengan jumlah 83 Sampel. teknik analisis \\
& untuk mengetahui hubungan status spiritual dengan kualitas hidup pada \\
& lansia menggunakan Uji Spearman. Hasil Penelitian ini sabagian besar status \\
& spiritual responden dapat dikategorikan tinggi sebanyak 48 orang (57,8\%) \\
& dan sabagian besar kualitas hidup responden dapat dikategorikan baik \\
& sebanyak 46 orang (55,4\%). Dapat disumpulkan Hasil uji Spearman Rho \\
& menunjukkan bahwa nilai Significancyp value = 0,004 (p < 0,005), artinya \\
& ada hubungan status spiritual dengan kualitas hidup pada lansia. Kualitas \\
& hidup merupakan perasaan subjektif seseorang mengenai kesejahteraan \\
& dirinya, berdasarkan pengalaman hidupnya saat ini secara keseluruhan, \\
& dimana Spiritual secara signifikan dapat membantu lansia dan memberi \\
& layanan untuk beradaptasi terhadap perubahan yang diakibatkan oleh \\
penyakit kronis.
\end{tabular}

\section{Key word:}

spiritual status, life quality, elderly

\begin{abstract}
Good spiritual owned by the elderly will help them in maintaining the relationship with God, people around, and environment, so that they can realize and know the purpose of life in the future. Elderly suffer from various health problems due to the vulnerability of many physical and mental disorders. Quality of life in the elderly can be influenced by many environmental factors. Quality of life tends to be good when the physical and psychological conditions are healthy and functioning properly. The research method used analytic correlation with cross-sectional design, the population in this study was the elderly who were more than 45 years old, the sampling technique was Simple Random Sampling with 83 samples. Analysis technique to determine the relationship betwen spiritual status with quality of life of the elderly used Spearman test. The results of this study said that most of the respondents' spiritual status can be categorized as high as 48 people (57.8\%) and most of the quality of life of respondents can be categorized as good as 46 people (55.4\%). In other words, it can be concluded that Spearman Rho test results indicated that Significancyp value $=0.004(\mathrm{p}<0.005)$. For the result, it means that there was a relationship between spiritual status and quality of life of elderly. Quality of life is a humans's subjective feelings about their well-being, based on their current life experience, in which spiritual significantly is able to help the elderly and provide services to adapt with changes caused by chronic disease.
\end{abstract}




\section{Introduction}

Aging process is a natural process that occurs since birth and it is experienced by all living things, in which each individual has a different aging process (Muhith \& Siyoto, 2016). Aging is an ongoing process (naturally going on) begin since birth and it is generally experienced by all living things (Hidayat, S. 2014). Other problems that are faced by elderly are psychosocial problems include behavioral disorders, dementia, post power syndrome of depression. For more information, nowday the elderly around the world is estimated more than 629 million, and in 2025 the elderly are predicted to reach 1.2 billion (Yusuf, et al , 2016).

In Indonesia, most of the elderly often face health problems in their living conditionthat are caused by decreasing body functions. Some processes which produce decline are biological, psycho, social, cultural and spiritual (Hidayat, Syaifurrahman, Mujib Hannan, L. H. and U. R. 2018).Elderly suffer from various health proble ms due to the vulnerability of many physical and mental disorders. Quality of life in the elderly can be influenced by many environmental factors. (Bishak, Dkk, 2014).

A study in Puducherry city, India said that the quality of life of elderly is a problem that is ignored especially in developing countries such as Indonesia. In some developing countries, the demographic transition deliver a higher life expectancies in increasing the elderly proportion. The population of elderly proportion is expected to be higher in urban areas than in rural areas, with the changing the elderly demographic pattern so that the population will also affect the distribution of health care resources (Syafinas, 2018).

The result of preliminary study with observation and interview conducted on March 2018 stated that the elderly didn't hold five daily prayers due to the unpraying society. It happened becausethey took high priorityfor daily work in fields as farmer and ignoring prayer times, the circumstance affecting to the elderly's daily activity which is ignore the praying time and always causing conflict in family interaction so that there is protracted anxiety without a clear destiny, lack of peace, increased physical and psychological pain, then for the rest it caused by lazying low self-esteem .

The problems that are faced by elderly frequentyare psychosocial problems and decreased organ function in which those can be recovered by improving their spiritual behavior well. Spirituality can affect suffering or happiness for elderly (Yusuf, et al, 2016). Good spiritual owned by elderly tends to help themin maintaining the relationship between the elderly and God, people around them, and environment. So that they can be aware and know th destiny of their future lives. Good spiritual will lead to positive behavior and then it helps elderly to improve behavior of living quality. Quality of life is categorized run well if the physical and psychological conditions functioning properly. Physical health, psychological well-being, social relations and relationships with the environment are some parts of the living quality that must be considered.

Decsreacing of body function is affected by reducing number of cells in the body because of aging process. It is indicated by lack of nutrients consumption, nasty environment because of the pollutions, lack of activity or regular daily exercise, so those all will affect to the internal organs such as brain organ which will interfere with its function. If the brain's function work inproperly, it will have an impact on coginitive function of elderly, that is known that elderly will suffer from dementia or forgetfulness and depression.

To overcome the problem, the elderly who have a good understanding of spiritual then get an impact on themselves, others, and environment around them can directly aim their life goals so that they can improve their quality of life, characterized by good physical and psychological conditions. If the elderly have good health, it will make the elderly easier to improve their 
quality of life. And for result, the goals of their live are meaningful, happy and useful.

\section{RESEARCH METHOD}

The research method used correlation analytic method with cross sectional design. The population in this study was more than 45 years old in Nambakor Village, Saronggi Subdistrict, Sumenep Regency with a total of 604 people and the sampling technique was Simple Random Sampling with 83 Samples. Analysis technique to determine the relationship between spiritual status with quality of life of the elderly using the Spearman Test.

\section{RESULT}

1. Respondence's characteristic based on age

Table 1 Distribution of respondence's characteristic frequency based on age in Nambakor village, Saronggi subdistrict, 2019

\begin{tabular}{cccc}
\hline No & \multicolumn{1}{c}{ Age } & F & (\%) \\
\hline 1. & $45-59$ & 50 & 60,24 \\
2. & $60-74$ & 30 & 36,15 \\
3. & $75-90$ & 3 & 3,61 \\
4. & $>90$ & 0 & 0 \\
\hline \multicolumn{2}{r}{ Total } & $\mathbf{8 3}$ & $\mathbf{1 0 0}$ \\
\hline
\end{tabular}

Source: prime data

Table 1 showed that most of responde's age are 45 years old in frequent of $50(60,24 \%)$

2. Respondence's characteristic based on genre

Table 2 Distribution of respondence's characteristic frequency based on genrein Nambakor village, Saronggi subdistrict , 2019

\begin{tabular}{clcc}
\hline No. & Genre & F & Presentage $(\boldsymbol{\%})$ \\
\hline 1 & Male & 31 & 37,3 \\
2 & Female & 52 & 62,7 \\
\hline \multicolumn{2}{c}{ Total } & $\mathbf{8 3}$ & $\mathbf{1 0 0}$ \\
\hline
\end{tabular}

Source: prime data

Table 2 showed that most of respondence's genre are female in frequent of $52(62,7 \%)$
3. Respondence's characteristic based education stage

Table 3 Distribution of respondence's characteristic frequency based on education stage in Nambakor village, Saronggi subdistrict, 2019

\begin{tabular}{ccc}
\hline Education & F & $\%$ \\
\hline Uneducated & 27 & 32,5 \\
Elementary school & 32 & 38,5 \\
Junior high school & 9 & 11 \\
Senior high school & 10 & 12 \\
Bachelor degree & 5 & 6 \\
\hline Total & $\mathbf{8 3}$ & $\mathbf{1 0 0}$ \\
\hline
\end{tabular}

Source: prime data

Table 3 showed that most of respondence's education stage are elementary school in frequent of $32(38,5 \%)$

Table 4 Elderly's spiritual status

Table 4 Distribution of respondence's characteristic frequency based on spiritual status of elderly in Nambakor village, Saronggisubdistrict, 2019

\begin{tabular}{clcc}
\hline No. & Spiritual Status & F & (\%) \\
1. & High & 48 & 57,8 \\
2. & Low & 35 & 42,2 \\
\hline & Total & $\mathbf{8 3}$ & $\mathbf{1 0 0}$ \\
\hline
\end{tabular}

Table 4 Distribution of respondence's characteristic frequency based on spiritual status of elderly in Nambakor village, Saronggisubdistrict, 2019

Table 5 Elderly's life quality

Table 5 Distribution of respondence's characteristic frequency based on life quality in Nambakor village, Saronggisubdistrict, 2019

\begin{tabular}{cccc}
\hline No. & Life Quality & F & $\mathbf{( \% )}$ \\
\hline 1. & Good & 46 & 55,4 \\
2. & Poor & 37 & 44,6 \\
\hline & Total & $\mathbf{8 3}$ & $\mathbf{1 0 0}$ \\
\hline
\end{tabular}

Table 5 showed that most of respondence's quality of live categorized in good level in frequent of $46(55,4 \%)$ 
Table 6 Distribution of respondence's characteristic frequency based on spiritual status related to life quality of elderlyin Nambakor village, Saronggisubdistrict, 2019

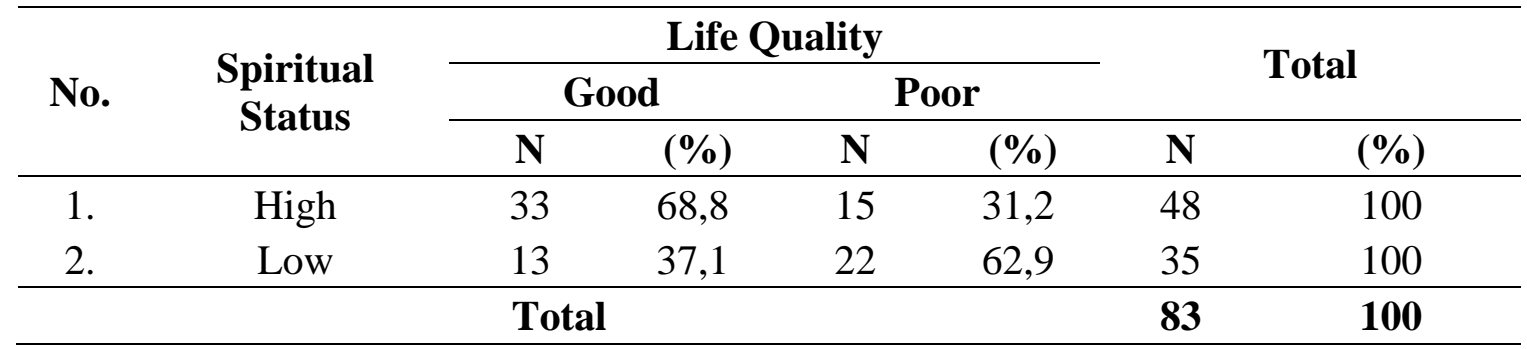

Table 6 showed that high level of spiritual statuses are 48 respondences related to life quality as many as $33(68,8 \%)$ while poor life quality as many as $15(31,3 \%)$. Low spiritual status as many as 35 respondences related to life quality as many as $13(37,1 \%)$ while poor life quality as many as 22 $(62,9 \%)$.

The result of Spearman Rho showed that Significancyp value is $0,004(p<0,005)$, means that there is a relationship between spiritual status with life quality of elderly in Nambakor village, Saronggi subdistrict. It can be concluded that $\mathrm{H} 0$ is rejected and $\mathrm{H} 1$ is accepted, $\mathrm{P}=0,005<0,05$. From the data analysis, researcher obtained data namely the spiritual status of the elderly in Nambakor village,Saronggi district that most of the respondents had a high spiritual status are 48 people $(57.8 \%)$. The results of the study based on the characteristics of the respondents showed that the majority of respondents were female. Religiosity and spirituality have a high level of involvement in religious and / or spiritual efforts of elderly by associated with increasing the prevalence of religious and spiritual activities throughout the world (Zimmer, Z., Jagger, C., Chiu, C., Beth, M., \& Rojo, F. 2016).

Spiritual is a dimension of wellbeing for the elderly and it can reduce stress and anxiety, maintain human existence and life goals. Spiritual significantly can help the elderly and provide services to adapt with the changing caused by chronic diseases. An elderly who has spiritual understanding tends to feel good relationship with others, so that they can find meaning and purpose in life, it can help the elderly achieve their potency and improve their life quality (Adegbola, 2006).

Happy and healthy elderly can only be achieved if the elderly feel physically, mentally / spiritually and socially are healthy, feel needed, feel loved, have pride and can participate in life. With the fulfillment of the highest needed called by spiritual, a person categorized has a good quality of life. Thus, it is appropriate for an elderly to be able to fulfill his spiritual needs. Psychosocial problems of elderly can be neutralized or eliminated by a strong spiritual understanding. Spirituality overcomes losses occuring throughout life with hope (Stanley \& Beare, 2012).

Based on the results of the study, the reseacher obtained data about the life quality of elderly in Nambakor Village, Saronggi Subdistrict. The data showed thatelderly whohave good quality of life reached 46 people $(55.4 \%)$. The problem of elderly's life quality and the determinants becomes an important point to clarify some problems of aging generation. Identification of the elderly can help the implementation of initiatives in improving the quality of life (Soosova, 2016).

Quality of life is an individual's perception of their position in life, detailly about context of culture and value systems in which they live related to their goals, standards, and concerns. Good quality of life is characterized by optimal functional 
conditions, so the elderly can enjoy their moment meaningfully, happily and useful (Sutikno, 2011). Quality of life is an individual's perception of their position in life, detailly about context of culture and value systems in which they live related to their goals, expectations, standards set, and attention. Basically, quality of life is recognized as a concept that represents individual's responses to physical, mental and social effects from illnesses in daily life.

Domains that are very important for quality of life are health and function of socio-economic, psychological, spiritual, and family. Health domains and functions include aspects such as usability to others and physical independence. Socio-economic domains related to living standard, environmental condition, friend, and so on. Psychological / spiritual domains include happiness, peace of mind, control of life, and other factors. Family domain includes happiness of family, children, spouse, and family health. Although it is difficult to dispose those, all four domains cover most of the important elements for quality of life.

Based on characteristics of the respondents' age in Nambakor Village, Saronggi Subdistrict, thedata showed most of them were 45-59 years old (Middle Age). The elderly got physical and behavioral changes when they reached a certain stage of development. The more they get old, the more degenerative aging process of elderly occured such as physical, psychosocial, social, emotional and sexual changes.Some elderlies say that they feel pain in knees, cramps, stiffness, obstacles when moved, and remembering abilitythat is poor. For an effect,those disruptelderlies activities . The condition faced by elderly because theygot various life problems in life not only these biological factors, but also psychological and social factors.

Decreasing the elderly's life quality is caused by disturbances and changes their sleeping quality. In rest, there are some disruption of daily activities and decreasing the body's immune system (Hidayat, S. and E. D. M. 2018).

Living quality related to the human life achievement that is ideal or in accordance with what they want. The measurement of elderly's life qualityconsists of four domains, namely physical health, psychological, social life and environment. At least, there are several factors make an elderly to be useful, namely; ability to adjust and accept all changes and setbacks experienced by the appreciation and reasonable treatment of his environment. Elderly's life quality can be influenced by themselves, family and economic community in their live, whereasif their spiritual status is low so their life quality gets low, when their spiritual status is high so their life qualty gets high. The spiritual wellbeing has several dimensions, they are cognitive dimensions and affective dimensions. Cognitive dimension relates to personal satisfaction while the dimension of affection is a person's life experience. Spiritual well-being refers to circumstances and positive feelings, behavior and cognition to interactone with others. For the transcendent dimension, giving individuals a sense of identity, integrity, satisfaction, beauty, love, respect, positive attitude, inner peace and harmony, purpose, and direction of life (Rioux \& Gonzalez, 2014).

Quality of life is a human's subjective feelings about his well-being, based on his current life experience as a whole. Quality of life describes the achievement of human life which is ideal or in accordance with what they want. Quality of life is directly affected by positive experiences of care, negative parenting experiences, and chronic stress. Economic resources and social resources have a direct impact on human's life quality.

Elderly feels a positive perception about quality of life by consistently or increasingly involved in productive physical activity, especially when facing several life events. (Hsin-YenYen, Li-JungLin, 2018). 
This result of the study is similar with preliminary study conducted by Yuzefo, Sabrian, Novayelinda (2015) which shows that 51 respondents who have high spiritual status, 32 respondents have good quality of life and the remaining 19 respondents have poor quality of life. ChiSquare test results of spiritual status relate to quality of life obtained $p$ value $0.034<0.05$ which indicated that there was a significant relationship between spiritual status and quality of life of elderly.

The elderly surrendered all destiny in God's and grateful on what was experienced at this time. The effort to carry out five daily prayers and sunnah prayers were the power of Allah SWT who provides peace of mind for informants, where higher judgments helped to behave towards the spiritual by running activities closer to God besides behaving towards health also help improve the chances of life and quality of life and life satisfaction of the elderly. Maturity of spiritual welfare will help the elderly to face reality, play an active role in life, and understand the meaning and goal of its existence in the world (Sunaryo, 2016)

In a study conducted by (Seraji, Maryam et al. 2017) showed that the elderly's life quality in the medium category stated that the status of social performance is better than physical health in which there was no significant relationship between education level and elderly's life quality

\section{Conclusions}

Most of spiritual status of elderly in Nambakor village, Saronggi subdistrict have high spiritual status, Most of spiritual status of elderly in Nambakor village, Saronggi subdistrict have high life quality. there is a relationship between spiritual status with life quality in Nambakor village, Saronggi subdistrict, Sumenep regency.

\section{Bibliography}

Adegbola, M. (2006). Spirituality and quality of life in chronic illness. Journal of theory construction testing;fall/winter2006, Vol. 10 Issue 2, $p 42$.

Bishak,Yaser Khaje, Laleh Payahoo,Bahram Pourghasem, and Mohammad Asghari Jafarabadi. 2014. Assessing the Quality of Life in Elderly People and Related Factors in Tabriz, Iran. Journal of Caring Siences.PMCID: PMC4334177

PMID: 25717455.

https://www.ncbi.nlm.nih.gov/pmc/a rticles/PMC4334177/

Hsin-YenYen Li-JungLin' . 2018. Quality of life in older adults: Benefits from the productive engagement in physical activity. Journal of Exercise Science \& Fitness. Volume 16, Issue 2, August 2018, Pages 49-54. https://www.sciencedirect.com /science/article/pii/S1728869X 17302289

Hidayat, S. (2014). Dzikir Khafi untuk Menurunkan Skala Nyeri Osteoartritis Pada Lansia. Jurnal Ilmu Kesehatan, $1(1)$, $13-22$. https://doi.org/https://doi.org/10.24 929/jik.vli1.119

Hidayat, S. dan E. D. M. (2018). Terapi Kombinasi Sugesti Dan Dzikir Dalam Peningkatan Kualitas Tidur Pasien. Care: Jurnal Ilmiah Ilmu Kesehatan, 6(3), 219-230. Retrieved from https://jurnal.unitri.ac.id/index.php/ care/article/view/953

Hidayat, Syaifurrahman, Mujib Hannan, L. H. dan U. R. (2018). Klenengan Music Therapy on Sleep Quality in Elderly Patients at Pratama. Journal of Medical Science and Clinical Research, 6(12), 107-112. https://doi.org/https://dx.doi.org/10 $.18535 / \mathrm{jmscr} / \mathrm{v} 6 \mathrm{i} 12.16$

Kholifah, S. N. (2016). Keperawatan Gerontik.Jakarta : Pusdik SDM Kesehatan

Muhith, A., Siyoto, S. (2016). Pendidikan Keperawatan Gerontik. Jakarta : CV ANDI OFFSET

Rioux, L., \& Gonzalez, L. (2014).The Spiritual Well-Being of Elderly People: AStudy of a French Sample. Journal of Springer, 1123-1137.

Stanley, M., Beare, Patricia.(2012). Buku Ajar Keperawatan Gerontik. (Edisi2). Jakarta: EGC.

Sunaryo, Wijayanti, R., Kuhu, M. M., Sumedi, T., Widayanti, E. D., Sukrillah, U. A., et 
al. (2016). Asuhan Keperawatan Gerontik. Yogyakarta: Penerbit Andi.

Soosova, Maria Sovariova, 2016. DETERMINANTS OF QUALITY OF LIFE IN THE ELDERLY. Centra Europian Juounal Nursing and Midwifwry. 7 (3):484-493 Department of Nursing Care, Faculty of Medicine, Pavol Jozef Šafárik University in Košice, Slovaki. http://periodicals.osu.eu/cejnm/5_1 25_determinants-of-quality-of-life-inthe-elderly.html

Syafinas. Azam, Adznam Siti Nur 'Asyura , Mun Chan Yoke, Ibrahim Zuriati , Taib Mohd Nasir Mohd, Hamzah Nur Aqlili Riana. 2018. Quality Of Life among Elderly: The View from Appetite and Anthropometry Characteristic Perspective. Elderly Health Journal 4(1): 4-10. Shahid Sadoughi University of Medical Sciences, Yazd, Iran. file://C:/Users/Adum_01/Download s/ssu-ehj-v4n1p4-en.pdf

Seraji, Maryam, Davoud Shojaeizadeh, Farideh Goldoos, (2017). Research Paper: Quality of Life of the Elderly Residing in Zahedan (South East of Iran). Iranian Rehabilitation Journal. Volume 15, Number 3 September
2017. http://irj.uswr.ac.ir/article-1665-en.pdf

Yusuf, ah, dkk.(2016). Kebutuhan Spiritual : Konsep dan Aplikasi dalam Asuhan Keperawatan.Jakarta : Mitra Wacana Media.

Yuzefo, M, A., Sabrian, F., Novayelinda R. (2015).Hubungan Status Spiritual dengan Kualitas Hidup Pada Lansia.Universitas Riau, Diakses tanggal 28 Agustus 2018.

Zimmer, Z., Jagger, C., Chiu, C., Beth, M., \& Rojo, F. (2016). SSM -Population Health Spirituality , religiosity , aging and health in global perspective: A review, 2, 373-381. Retrieved from https://reader.elsevier.com/reader/s d/pii/S2352827316300179?token=B0 2474D3E67B2FE1D72342128DCCE3D 1B934F86E744E451348C4EE3012F71 B1CDFF5B0DA7C5ECDFC4346F47EEA E309BA 